\title{
AREA USE AND IMPORTANT AREAS FOR COMMON TERN Sterna hirundo INLAND POPULATIONS BREEDING IN SLOVENIA AND CROATIA
}

\section{Raba območij in pomembna območja celinske populacije navadne čigre Sterna birundo v Sloveniji in na Hrvaškem v času gnezdenja}

\author{
Davorin Tome ${ }^{1}$, Miloš Martinović ${ }^{2}$, Jelena Kralj ${ }^{2}$, Luka Božič ${ }^{3}$, Tilen Basle ${ }^{3}$, Luka Jurinovićc \\ Nacionalni inštitut za biologijo, Večna pot 111, SI-1000, Slovenia, e-mail: davorin.tome@nib.si \\ Hrvatska akademija znanosti i umjetnosti, Zavod za ornitologiju, Gundulićeva 24, 10000 Zagreb, Croatia, \\ e-mail:martinovic@hazu.hr,jkralj@hazu.hr \\ 3 DOPPS - BirdLife Slovenia, Tržaška cesta 2, SI-1000 Ljubljana, Slovenia, e-mail: luka.bozic@dopps.si, tilen. \\ basle@dopps.si \\ 4 Hrvatski veterinarski institut, Centar za peradarstvo, Heinzelova 55, 10000 Zagreb, Croatia, e-mail: luka. \\ jurinovic@gmail.com
}

During the breeding periods of 2018 and 2019 we investigated the extent of areas Common Terns Sterna hirundo use while searching for food. We used GPS-UHF tags to follow the movements of 23 terns from Slovenia (7 individuals) and Croatia (16 individuals). We investigated the movements of birds from three breeding sites, i.e. Lakes Ptuj, Siromaja 2 and Rakitje. Conclusions are based on 43,105 locations which were collected with a frequency of one reading per 20 minutes during the day and one reading per 4 hours during the night.

In Slovenia, terns used a $60 \mathrm{~km}$ long and narrow area over Stara struga Drave (former river-bed of the Drava River) between Ormož and Maribor as well as eleven fishponds / lakes in its surroundings, most of them in the Pesnica valley. The most distant location was $30 \mathrm{~km}$ of straight line from breeding islands, but it was visited only once by a single tern. The areas with the most locations, hence important areas, were Lake Ptuj, Drava at Ptuj, Stara struga Drave between Ptuj and Rošnja and about $20 \mathrm{~km}$ distant Lakes Radehova and Gradiško. These were probably the most important feeding areas for Common Terns breeding on Lake Ptuj. In Croatia, terns were found along the Sava almost exclusively, with only a few visits more than $2 \mathrm{~km}$ from the river. The most distant locations were over $60 \mathrm{~km}$ away from the breeding grounds, but terns visited them only rarely. Most locations of terns nesting on Siromaja were within a $5 \mathrm{~km}$ radius, while terns from Rakitje were making regular flights to waters up to $23 \mathrm{~km}$ from their colony. The area with the most locations visited by terns from both colonies was the Sava at Hrušćica. Besides, birds from the Rakitje colony were frequently recorded on the Sava near Savica and waterbodies within $5 \mathrm{~km}$ of the colony. These were probably the most important feeding areas for Common Terns breeding around Zagreb.

Key words: Common Tern, foraging areas, GPS-UHF tags, home range, Drava, Sava

Ključne besede: navadna čigra, območja prehranjevanja, GPS-UHF oddajniki, Drava, Sava 
D. Tome et al.: Area use and important areas for Common Tern Sterna hirundo inland populations breeding in Slovenia and Croatia

\section{Introduction}

Bird abundance and distribution is limited by suitable habitats. Among the most important factors affecting habitat suitability are quality of nest-site, food supply and "enemies", being predators, parasites or competitors (Newton 2007). Common Terns Sterna hirundo nest close to large water bodies on flat, scarcely vegetated surfaces (NISBET 2002). Sea coast seems like a very spacious breeding area for them, but only very specific habitats meet all criteria for nest-site selection. In Croatia, for example, although abundant with sea coast, only 200-500 pairs are presumed to nest along the sea (KRALJ et al. 2013). In marine ecosystems in Slovenia, terns nest at artificially maintained Sečovlje saltpans and in carefully managed Škocjanski zatok Nature Reserve (ŠKORNIK 2012).

Inland, the most often occupied natural breeding sites of Common Terns are gravel islands and banks in the areas of large rivers and lakes, where predators have limited access (BECKER \& LUDWIGS 2004). Nowadays, due to countless changes made in freshwater ecosystems by humans, these are among the rarest and most endangered habitats in Europe (EEA 2015). Hence terns are more and more diverted to nest in artificial areas and structures like gravel pits and nesting rafts. In Slovenia, the only permanent breeding site of Common Terns are artificial islands on Lake Ptuj on the Drava River (DenAc et al. 2019), where they've nested since the reservoir was created in 1978 (JANŽEKOVIČ \& ŠTUMBERGER 1984). In 2017, another breeding island was created on Brežice HPP reservoir on the Sava River. Common Terns bred there in 2018 and 2019, but whether this is to become another regular breeding site for Slovenia remains to be seen. In Croatia, regularly nesting terns can be found on two locations near the Sava River (Hrušćica and Rakitje) and two on the Drava (Lake Ormož and Drava River close to Repaš), while occasional breeding in smaller numbers also occurs at various fishponds of continental Croatia. The population of inland breeding Common Terns in both countries is estimated at 300-500 breeding pairs. Being so scarce and vulnerable, most breeding sites are strictly protected by law (BožIČ 2003, RADOvić et al. 2005) and well managed (DENAC \& BožIČ 2018, MarTinović 2018). Still, to run an efficient protective breeding program for Common
Terns, other factors important for suitability of the habitat should be controlled, too, in particular food. In Slovenia and Croatia, there have been no reports in this respect, beside notes on sporadic observations of terns foraging on different locations during the breeding season (e.g. VoGRIN 2016).

While breeding and when not on or near the nest, Common Terns spend a lot of their time flying over shallow waters, where they search for food, mainly fish up to $15 \mathrm{~cm}$ long (BECKER \& LuDwigs 2004), which they catch by plunge-diving from the air (HolBECH et al. 2018). Beside for themselves, they use the catch for feeding their unfledged chicks. Since this means collecting food at some distant sources and carrying it to a nest (usually one by one), that makes them "central place foragers” (WETTER 1989, DÄNHARD et al. 2011). The optimal foraging theory predicts that the distance to which they fly during the hunt is somehow limited by economics (PyKe 1984) - they can afford longer flights if food there is more abundant, easier to catch or energetically more profitable. But in general, the radius of activity of breeding terns is usually between 3 and $10 \mathrm{~km}$, exceptionally up to $30 \mathrm{~km}$ (NISBET 2002) from the nest.

Locations of nests, numbers and breeding success are relatively well known for inland populations of Common Tern in Slovenia and Croatia (Kralj 2018, Minelič et al. 2019). On the other hand, food and feeding habits are virtually unknown, so we designed this study to complement our knowledge appropriately. Our aim was (1) to find the whole extent of areas adult terns use during the breeding season (area use) and (2) to find which are the most used ones (i.e. most important). Since we did not observe the terns physically, we only presume that the majority of activities when not on or by the nest were to locate and catch the prey (feeding activity), although we realize that some were also due to other needs, like flying, prospecting, etc. (MARTINOvić et al. 2019).

\section{Study area}

\subsection{Slovenia}

In Slovenia, the study was conducted on Lake Ptuj, where Common Terns nest, and in its surrounding areas (Figure 1). Lake Ptuj is an artificial water 


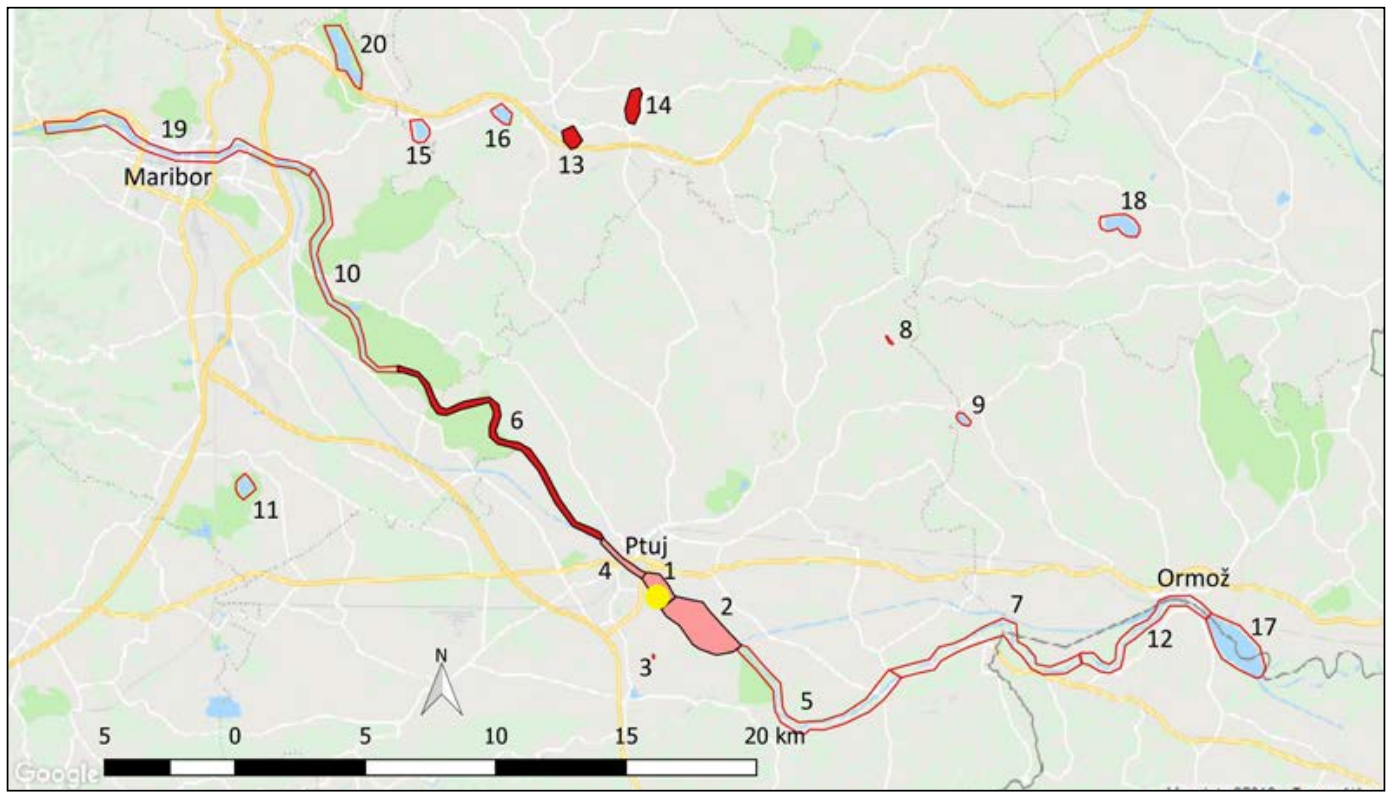

Figure 1: Areas used by Common Terns in Slovenia are presented with outlined polygons. Numbers correspond to numbers in Table 2. Filled in red important foraging areas, filled in pink important areas for foraging and as flying corridors. Yellow circle denotes position of breeding island.

Slika 1: Raba območij navadnih čiger v Sloveniji, označena s poligoni. Številke ustrezajo območjem v tabeli 2. Rdeča so območja, pomembna za prehranjevanje, rožnata pa območja, pomembna za prehranjevanje in kot preletni koridorji. Rumeni krog označuje položaj gnezdišča.

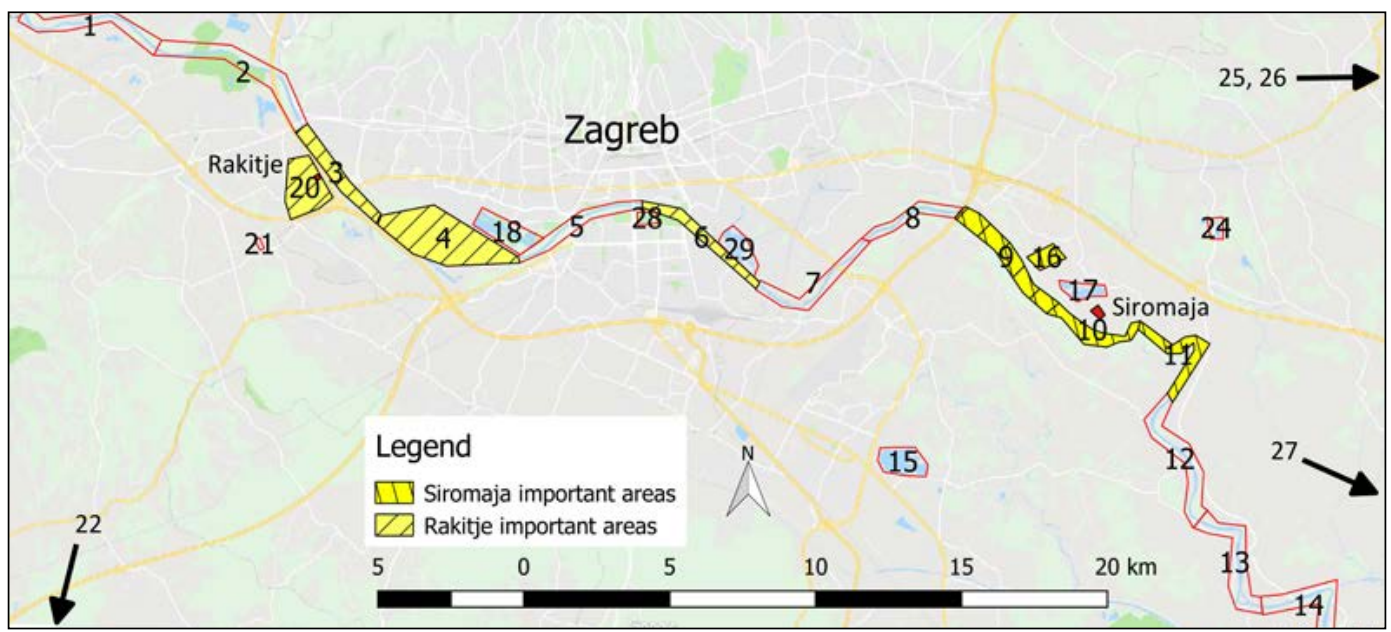

Figure 2: Areas used by Common Terns in Croatia are presented with outlined polygons. Numbers correspond to numbers in Tables 3 and 4. Important foraging areas are filled in yellow, with crossbars indicating the colony for which these areas are deemed important (see Legend). Breeding colonies are filled in red.

Slika 2: Raba območij navadnih čiger na Hrvaškem, označena s poligoni. Številke ustrezajo območjem v tabelah 3 in 4. Rumena so območja, pomembna za prehranjevanje z različnimi šrafurami za obe koloniji (glej legendo). Rdeči poligoni označujejo položaj gnezdišč. 
D. Tome et al.: Area use and important areas for Common Tern Sterna hirundo inland populations breeding in Slovenia and Croatia

body constructed in 1978 on the Pannonian stretch of the Drava River as reservoir for the channel-type hydropower plant Formin. It is $7.3 \mathrm{~km}$ long and $1.2 \mathrm{~km}$ wide, with its surface area covering 346 ha. In recent years, terns have been nesting there on two gravel islands (both covering $1,100 \mathrm{~m}^{2}$ ) constructed in 2014, while other islands are occupied mainly by Black-headed Gulls Larus ridibundus (Božıč \& Denac 2014).

To the north of the lake spreads the town of Ptuj, while other parts of its surroundings are mostly intensive cultural landscapes with many fields, some hedgerows and villages. About $19 \mathrm{~km}$ further north is a series of seven lakes in the Ščavnica and Pesnica valleys. About $18 \mathrm{~km}$ to the $\mathrm{W}$ is a series of fishponds near the village of Rače and Medvedce reservoir. In other directions within this perimeter are some other small fish ponds, mostly without official names. The Drava River represents both the inflow and the outflow to and from Lake Ptuj. The original riverbed is in both sections complemented with an artificial, concrete channel, used to bring water to the power plant. Most of the water throughout the year is diverted to the channel, leaving the riverbed with only a small volume of water flow $\left(20 \mathrm{~m}^{3} / \mathrm{s}\right.$ upstream and $10 \mathrm{~m}^{3} / \mathrm{s}$ downstream of Lake Ptuj during the Common Tern breeding season).

\subsection{Croatia}

The Croatian part of the study was conducted along the Sava River in the surroundings of Zagreb (Figure 2). Terns were tagged on Lake Siromaja 2, a gravel pit with a floating breeding platform about $15 \mathrm{~km}$ downstream (SE) from the city of Zagreb, and on Lake Rakitje just off the W edge of Zagreb with a fairly large colony on an artificial island. The Sava River is mostly regulated and canalized all the way through Zagreb, with semi-natural flows upstream from Rakitje, about $10 \mathrm{~km}$ to the Slovenian border, as well as downstream from Ivanja Reka (SLUKAN Altić 2010). The part downstream from Ivanja Reka is protected as a Natura 2000 site "Sava kod Hrušćice" (RADOvić et al. 2005.), and this area includes numerous small gravel pits, including Siromaja 2. There are numerous other gravel pits all along the Sava through and around Zagreb. The air distance between Siromaja 2 and Rakitje lakes is $27 \mathrm{~km}$ and $31.5 \mathrm{~km}$ along the river.

\section{Material and methods}

\subsection{Field work}

We used the GPS-UHF solar-powered Nano-tags produced by Milsar, attached to birds with Teflon chest harness, to collect data on the movements by Common Terns. The device with harness weighed about $4 \mathrm{~g}$, representing about $3.5 \%$ of body mass of the tern. While fitting the tags, we also marked the birds with stainless steel on one and plastic ring on the other leg.

Adults were captured on the nest using nest traps as late as possible during the incubation period. According to observations from a distance and some visits to the breeding colony, not all terns with tags successfully fledged their chicks. If a tagged bird deserted the nest before chick was hatched or in case of malfunction of the tag, the collected data was not included in the analysis.

Loggers collected GPS fixes every $20 \mathrm{~min}$ during daylight ( 4 am to $10 \mathrm{pm}$ ) and every $4 \mathrm{hrs}$ during nighttime. GPS location accuracy was $10 \mathrm{~m}$ for $90 \%$ of the records (manufacturer specifications). We regularly downloaded data to a computer using an omnidirectional antenna connected to a base station.

\subsection{Data analysis}

We define a location as a single geographic coordinate recorded by a tag. We used Google Earth and QGIS (QGIS Development Team 2016) to graphically present distribution of all locations of all terns within the study site. As expected, locations were clustered around different water bodies ( rivers, lakes, submerged gravel pits, fish ponds, etc.). We visually defined each cluster within separate water body as a separate area. In Slovenia, large areas (in particular long water courses) were further separated into two or three smaller sub-areas (in the text referred to as "the area” for sub-areas too). In Croatia, the Sava River was divided into 14 segments, each of roughly $5 \mathrm{~km}$ in length. Additionally, as a nesting area, we defined islands or rafts where Common Terns nested, even if they were located within one of the larger areas.

We used MS Excel to analyze distribution of locations according to the defined areas. Each area 
was geo-fenced with a four corner polygon. For each location and each line of the polygon, we computed the value

$$
\mathrm{d}=(\mathrm{x}-\mathrm{x} 1)(\mathrm{y} 2-\mathrm{y} 1)-(\mathrm{y}-\mathrm{y} 1)(\mathrm{x} 2-\mathrm{x} 1)
$$

$(\mathrm{x}, \mathrm{y}=$ coordinates of location; $\mathrm{x} 1, \mathrm{y} 1=$ coordinates of one end of the line; $\mathrm{x} 2, \mathrm{y} 2$ coordinates of the other end of the line)

to determine on which side of the line is the given location. If $\mathrm{d}>0$ the location was on one side, if $\mathrm{d}<0$ the location was on the other side, and if $\mathrm{d}=0$ the location was exactly on the line. The final result after testing for all four lines of a particular polygon was information whether the location was inside or outside the polygon surrounding a specific area.

To find which areas within home range were most often used, hence important for Common Terns (beside nesting area which was regarded as important by default), we first removed all locations from within the nesting area. For remaining locations, we used three aspects to highlight the level of importance of particular area:

(1): Cumulative number of locations of all terns in a specific area. Subjectively we considered the area as an important site if it contained more than $10 \%$ of all locations.

(2): The number of terns detected within a specific area. Subjectively we considered an area as a candidate for an important site if more than half of terns ( 4 for Slovenia, 2 for Croatia-Rakitje and 6 for Croatia-Siromaja) had at least one location within a specific area.

(3): Number of terns commonly present in a specific area. As commonly present we considered birds with at least $10 \%$ of locations in the particular area. With this aspect also birds with short monitoring period influence a selection of important areas. A candidate for an important site should have at least one regular visitor.

In the end we defined an area as an important site for Common Terns during the breeding season if it corresponded with the first aspect or if it was a candidate according to both other aspects.

\section{Results}

We analyzed data from 23 loggers (7 in Slovenia and 16 in Croatia) which were collecting locations of terns for 5 or more consecutive days (Table 1).
In Slovenia, loggers attempted to record location 10,781 times. In 631 of these attempts (5.8\%), GPS unit failed to connect to satellites within the pre-programmed time and record coordinates, or the registered location was erroneous. The rest were valid locations. 701 valid locations (6.9\%) were disregarded due to being outside the selected areas mostly from birds recorded while flying from breeding areas over land to foraging areas or

Table 1: Statistics of tracking effort of Common Terns with GPS tags; CN = individual code number of the tern, $\mathrm{CO}=$ country, $\mathrm{FD}=$ date of first record; $\mathrm{LD}=$ date of last record; NR = Number of readings

Tabela 1: Statistika zbiranja GPS podatkov na navadni čigri; $\mathrm{CN}=$ individualna koda osebka, $\mathrm{CO}=$ država, $\mathrm{FD}=$ datum prvega podatka; LD = datum zadnjega podatka; NR = število podatkov

\begin{tabular}{rrrrr}
\hline CN & CO & FD & LD & NR \\
\hline 961002 & SI & $5 / 27 / 2018$ & $7 / 21 / 2018$ & 2019 \\
961003 & SI & $5 / 19 / 2018$ & $7 / 11 / 2018$ & 2313 \\
961004 & SI & $5 / 19 / 2018$ & $7 / 2 / 2018$ & 1809 \\
961007 & SI & $5 / 19 / 2018$ & $5 / 23 / 2018$ & 184 \\
961009 & SI & $5 / 23 / 2018$ & $5 / 27 / 2018$ & 239 \\
961014 & SI & $5 / 23 / 2018$ & $7 / 2 / 2018$ & 1897 \\
961020 & SI & $5 / 20 / 2019$ & $6 / 15 / 2019$ & 988 \\
961020 & CRO & $6 / 20 / 2018$ & $7 / 19 / 2018$ & 1535 \\
961021 & CRO & $6 / 5 / 2018$ & $7 / 20 / 2018$ & 2634 \\
961022 & CRO & $6 / 6 / 2018$ & $8 / 1 / 2018$ & 2470 \\
961023 & CRO & $6 / 5 / 2018$ & $7 / 12 / 2018$ & 1082 \\
961024 & CRO & $6 / 5 / 2018$ & $7 / 26 / 2018$ & 2894 \\
961025 & CRO & $6 / 17 / 2018$ & $8 / 1 / 2018$ & 1758 \\
961026 & CRO & $6 / 11 / 2018$ & $7 / 20 / 2018$ & 1061 \\
961028 & CRO & $6 / 26 / 2018$ & $8 / 12 / 2018$ & 2315 \\
961029 & CRO & $6 / 5 / 2018$ & $8 / 1 / 2018$ & 2720 \\
961030 & CRO & $6 / 8 / 2018$ & $7 / 12 / 2018$ & 2085 \\
961031 & CRO & $6 / 8 / 2018$ & $7 / 20 / 2018$ & 2387 \\
961032 & CRO & $6 / 8 / 2018$ & $7 / 19 / 2018$ & 2372 \\
961033 & CRO & $6 / 8 / 2018$ & $8 / 1 / 2018$ & 2905 \\
961034 & CRO & $6 / 11 / 2018$ & $7 / 26 / 2018$ & 2308 \\
961035 & CRO & $6 / 11 / 2018$ & $7 / 20 / 2018$ & 1490 \\
961036 & CRO & $6 / 11 / 2018$ & $7 / 14 / 2018$ & 1690 \\
\hline & & & &
\end{tabular}


D. Tome et al.: Area use and important areas for Common Tern Sterna hirundo inland populations breeding in Slovenia and Croatia

Table 2: Number of locations in particular areas for Common Terns from Lake Ptuj. Area - geographic name of the area (RD - former Drava river-bed); distance - from breeding island/raft to centroid of the area; \% locations percentage of locations (according to column "all terns"); $\mathrm{N}>=10 \%$ - number of terns with $>=10 \%$ of locations in particular area (common visitors of the area); $\mathrm{N}$ - number of terns recorded in the area. Shaded are important areas and numbers reaching the threshold for selection of important area.

Tabela 2: Število lokacij v posameznih območjih za čigre s Ptujskega jezera. Area - ime območja (RD - stara struga Drave); distance - razdalja med gnezdiščem in centroidom območja; \% locations - odstotek lokacij (iz kolone "all terns"); $N=10 \%$. število čiger, ki so imele >= $10 \%$ lokacij v izbranem območju (redne obiskovalke); $N$ - število čiger, zabeleženih v območju. Osenčena so pomembna območja za čigre in vrednosti, ki dosegajo mejo za določanje pomembnih območij.

\begin{tabular}{|c|c|c|c|c|c|c|c|c|c|c|c|c|c|}
\hline \multirow[t]{2}{*}{ Area } & \multicolumn{11}{|c|}{ Code number of individual tern } & \multicolumn{2}{|c|}{ statistics } \\
\hline & 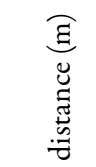 & $\begin{array}{l}\tilde{\delta} \\
\stackrel{0}{0} \\
\text { }\end{array}$ & $\begin{array}{l}\tilde{8} \\
\stackrel{0}{0}\end{array}$ & $\begin{array}{l}\stackrel{+}{\circ} \\
\stackrel{0}{0} \\
2\end{array}$ & $\begin{array}{l}\hat{\circ} \\
\stackrel{0}{\sigma} \\
\stackrel{2}{2}\end{array}$ & $\begin{array}{l}\stackrel{\partial}{\circ} \\
\text { ठे } \\
\text { }\end{array}$ & $\begin{array}{l}\underset{\sigma}{ } \\
\frac{0}{\sigma}\end{array}$ & $\begin{array}{l}\text { ते } \\
\text { 잉 }\end{array}$ & 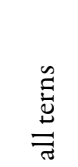 & 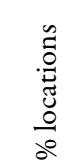 & $\begin{array}{l}\stackrel{0}{0} \\
\stackrel{1}{1} \\
\hat{z}\end{array}$ & Z & 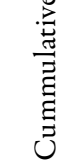 \\
\hline breeding islands & 0 & 1035 & 654 & 1132 & 87 & 111 & 261 & 700 & 3980 & 100,0 & & & \\
\hline 1 lake Ptuj - N & 800 & 258 & 273 & 55 & 45 & 30 & 114 & 41 & 816 & 14.9 & 5 & 7 & 14.9 \\
\hline 2 lake Ptuj - S & 1700 & 59 & 544 & 29 & 9 & 0 & 3 & 21 & 665 & 12.2 & 1 & 6 & 27.1 \\
\hline 3 fish pond near Ptuj & 2000 & 57 & 2 & 0 & 0 & 0 & 0 & 0 & 59 & 1.1 & 0 & 2 & 28.2 \\
\hline 4 Drava at Ptuj & 2100 & 187 & 129 & 5 & 4 & 34 & 94 & 49 & 502 & 9.2 & 3 & 7 & 37.3 \\
\hline $\begin{array}{l}5 \text { RD Markovci to } \\
\text { Ormož - E }\end{array}$ & 5500 & 1 & 31 & 0 & 1 & 0 & 1 & 0 & 34 & 0.6 & 0 & 4 & 38.0 \\
\hline 6 RD Ptuj - Rošnja & 7600 & 269 & 378 & 5 & 13 & 59 & 1147 & 176 & 2047 & 37.4 & 6 & 7 & 75.4 \\
\hline 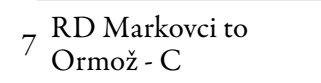 & 9500 & 0 & 1 & 0 & 0 & 0 & 2 & 0 & 3 & 0.1 & 0 & 2 & 75.4 \\
\hline $\begin{array}{l}\text { fish ponds at } \\
\text { Bodkovci }\end{array}$ & 13200 & 1 & 89 & 0 & 0 & 0 & 0 & 0 & 90 & 1.6 & 0 & 2 & 77.1 \\
\hline 9 lake Savci & 13500 & 1 & 36 & 0 & 0 & 0 & 0 & 0 & 37 & 0.7 & 0 & 2 & 77.8 \\
\hline 10 RD Rošnja - Maribor & 15700 & 1 & 2 & 0 & 0 & 5 & 11 & 0 & 19 & 0.3 & 0 & 4 & 78.1 \\
\hline 11 fish ponds at Rače & 16500 & 1 & 103 & 0 & 0 & 0 & 0 & 0 & 104 & 1.9 & 0 & 2 & 80.0 \\
\hline $\begin{array}{l}12 \text { RD Markovci to } \\
\text { Ormož - W }\end{array}$ & 16500 & 0 & 4 & 0 & 3 & 0 & 13 & 0 & 20 & 0.4 & 0 & 3 & 80.4 \\
\hline 13 lake Radehova & 19000 & 129 & 0 & 406 & 10 & 0 & 198 & 0 & 743 & 13.6 & 4 & 4 & 94.0 \\
\hline 14 lake Gradiško & 19500 & 10 & 0 & 87 & 5 & 0 & 46 & 1 & 149 & 2.7 & 1 & 5 & 96.7 \\
\hline 15 lake Pristava & 21000 & 1 & 0 & 6 & 0 & 0 & 6 & 0 & 13 & 0.2 & 0 & 3 & 96.9 \\
\hline 16 lake Komarnik & 21200 & 0 & 0 & 3 & 0 & 0 & 0 & 0 & 3 & 0.1 & 0 & 1 & 97.0 \\
\hline 17 lake Ormož & 22000 & 0 & 32 & 0 & 7 & 0 & 1 & 0 & 40 & 0.7 & 0 & 3 & 97.7 \\
\hline 18 Gajševsko lake & 23000 & 0 & 22 & 0 & 0 & 0 & 0 & 0 & 22 & 0.4 & 0 & 1 & 98.1 \\
\hline 19 Drava at Maribor & 25000 & 0 & 13 & 0 & 0 & 0 & 0 & 0 & 13 & 0.2 & 0 & 1 & 98.4 \\
\hline 20 lake Pernica & 25000 & 9 & 0 & 81 & 0 & 0 & 0 & 0 & 90 & 1.6 & 1 & & 100.0 \\
\hline $\begin{array}{l}\text { all areas w/o breeding } \\
\text { islands }\end{array}$ & & 984 & 1659 & 677 & 97 & 128 & 1636 & 288 & 5469 & & & & \\
\hline
\end{tabular}


vice versa. In Croatia there were 38,172 recording attempts, $1,186(3.1 \%)$ of them failed to record valid coordinates, 3,421 (9.2\%) valid records were disregarded for the same reason as in Slovenia. After exclusion of erroneous and disregarded readings, we were left with 43,105 locations used for analysis (9,449 in Slovenia and 33,565 in Croatia).

\subsection{Slovenia}

In Slovenia, we determined 21 areas of activity (Figure 1, Table 2). One area was composed of two breeding islands, located within the larger area of Lake Ptuj. The most distant areas from breeding islands were Lake Pernica (20 in Table 2) and the Drava River at Maribor (19), which both have centroids about $25 \mathrm{~km}$ of straight line from breeding islands.

A little more than $42 \%$ of analyzed locations were from breeding islands (Table 2). More than one third of the remaining recordings were from the Drava Riverbed between Ptuj and Rošnja (6 in Table 2; 2,047 locations or 37\%) which was, beside breeding islands, the most used area. From the section of the Drava river-bed between Rošnja and Maribor (10) there were only 19 recorded locations.

Within Lake Ptuj (without breeding islands), terns were documented 1,481 times ( $27 \%$ of locations), with the $\mathrm{N}$ part of the lake (1) having only marginally more locations than the $S$ part $2 ; 815$ or $15 \%$ compared to 665 or $12 \%)$. The only other area with over 10\% of locations was Lake Radehova (13; 743 locations or $14 \%$ ), while the Drava at Ptuj (4) came very close to $10 \%$ threshold (502 locations or $9 \%$ ).

Of the remaining areas, Lake Gradiško (14), fish ponds at Rače (11), small fishponds at Bodkovci (8), Lake Pernica (20) and a small fish pond near Ptuj (3) each had more than $1 \%$ of locations. The remaining ten areas combined had 3.6\% locations. The entire Stara struga Drave between Markovci and Ormož, although more than $20 \mathrm{~km}$ in length, had only 57 locations.

The part of the Drava river-bed between Ptuj and Rošnja (6), the Drava at Ptuj (4) and N part of Lake Ptuj (1) were used by all 7 terns, although the percentage of locations was rather unequally distributed among individual birds (from $1 \%$ to $70 \%)$. Five or six birds used the S part of Lake Ptuj (2), the part of Stara struga Drave between Rošnja and Maribor (10) and Lake Gradiško (14). Four birds used the E part of Stara struga Drave between Markovci and Ormož (5), as well as Lake Radehova (13). Two areas with a relatively high number of locations, a small fish pond at Bodkovci (8) and fish ponds at Rače (11), were used mostly by one bird only (individual code number 961003). This bird was responsible for $99 \%$ of all locations in these two areas.

The areas where at least one tern was commonly present were: Lake Ptuj (1,2), the Drava at Ptuj (4), part of Stara struga Drave between Ptuj and Rošnja (6), Lake Gradiško (14), Lake Radehova (13) and Lake Pernica (20).

\subsection{Croatia}

Results from colonies around Zagreb are shown in Tables 3 and 4 and Figure 2. We identified 28 areas where terns were recorded during the study ( 20 for birds breeding on Siromaja 2 and 24 for birds breeding on Rakitje). Two were the breeding colonies themselves, although each also served as a visiting area for birds from the other colony. The Rakitje colony was itself situated within the larger Lake Rakitje (20 in Tables 3 and 4). The most distant areas from breeding islands were Sišćani (26) and Garešnica-Poljana fishponds (27), the former with a centroid of about $60 \mathrm{~km}$ of straight line from Rakitje, and the latter about $65 \mathrm{~km}$ from Siromaja 2.

For birds breeding on Siromaja, $70.9 \%$ of all GPS fixes were within boundaries of the colony lake. Almost half of all other fixes were on the Sava at Hrušćica (9). The next most popular sites were Abesinija Lake (16), the Sava at Siromaja (10) and the Sava at Rugvica (11). The remaining 23 areas accounted for only $6.4 \%$ of locations outside the colonies.

Birds breeding at the Rakitje colony had 57.0\% of all GPS locations at the colony itself. They also had the highest share of their non-colony fixes, one quarter of them, on the Sava at Hrušćica (9). Rakitje Lake (20) was the next most popular site, while the rest of the locations were slightly more evenly scattered along the Sava River, most notably the Sava near Savica (6) and the Sava at Blato (4). More than a quarter of non-colony locations were spread out along the seven other areas of the Sava between Strmec and Rugvica, as well as on Lakes 
D. Tome et al:: Area use and important areas for Common Tern Sterna hirundo inland populations breeding in Slovenia and Croatia

Table 3: Number of locations in particular areas for Common Terns from Siromaja 2. Abbreviations the same as in Table 2.

Tabela 3: Število lokacij v posameznih območjih za čigre s Siromaje 2. Okrajšave enake kot v tabeli 2.

\begin{tabular}{|c|c|c|c|c|c|c|c|c|c|}
\hline & \multicolumn{9}{|l|}{ Area } \\
\hline & & distance $(\mathrm{m})$ & 961021 & 961023 & 961024 & 961026 & 961029 & 961030 & 961031 \\
\hline & Siromaja colony & & 2160 & 667 & 1794 & 898 & 1506 & 1769 & 2134 \\
\hline 10 & Sava at Siromaja & 700 & 125 & 34 & 234 & 35 & 152 & 85 & 58 \\
\hline 17 & Rugvica lakes & 1000 & 3 & 2 & 27 & 4 & 5 & 3 & 2 \\
\hline 16 & Abesinija lake & 2700 & 5 & 268 & 326 & 22 & 220 & 9 & 7 \\
\hline 11 & Sava at Rugvica & 3100 & 48 & 18 & 4 & 32 & 45 & 4 & 67 \\
\hline 9 & Sava at Hrušćica & 3900 & 274 & 35 & 509 & 68 & 750 & 211 & 92 \\
\hline 12 & Sava Novaki-Oborovo & 5500 & 3 & 6 & 0 & 1 & 1 & 0 & 0 \\
\hline 8 & Sava at Ščitarjevo & 7200 & 4 & 2 & 0 & 1 & 4 & 1 & 0 \\
\hline 15 & Čiče lake & 8200 & 0 & 0 & 0 & 0 & 37 & 0 & 0 \\
\hline 13 & Sava Oborovo-Prevlaka & 9400 & 1 & 0 & 0 & 0 & 0 & 0 & 0 \\
\hline 7 & Sava at Petruševec & 9700 & 3 & 3 & 0 & 0 & 0 & 2 & 3 \\
\hline 14 & Sava Prevlaka-Prerovec & 13500 & 0 & 1 & 0 & 0 & 0 & 0 & 0 \\
\hline 6 & Sava near Savica & 14500 & 6 & 3 & 0 & 0 & 0 & 1 & 1 \\
\hline 5 & Sava Jarun-Bundek & 18000 & 0 & 1 & 0 & 0 & 0 & 0 & 2 \\
\hline 4 & Sava at Blato & 23100 & 0 & 3 & 0 & 0 & 0 & 0 & 11 \\
\hline \multirow[t]{2}{*}{3} & Sava at Rakitje & 26500 & 0 & 2 & 0 & 0 & 0 & 0 & 0 \\
\hline & Rakitje colony & 27100 & 0 & 17 & 0 & 0 & 0 & 0 & 5 \\
\hline 20 & Rakitje lake & 27500 & 0 & 3 & 0 & 0 & 0 & 0 & 0 \\
\hline 21 & Kerestinec & 28800 & 0 & 0 & 0 & 0 & 0 & 0 & 0 \\
\hline \multirow[t]{2}{*}{27} & $\begin{array}{l}\text { Garešnica-Poljana } \\
\text { fishponds }\end{array}$ & 65200 & 0 & 0 & 0 & 0 & 0 & 0 & 0 \\
\hline & all areas w/o colony & & 472 & 398 & 1100 & 163 & 1214 & 316 & 248 \\
\hline
\end{tabular}

Abesinija (16) and Jarun (18). The remaining 15 areas made up the remaining $3.8 \%$ of non-colony locations.

The Sava at Siromaja (10), Rugvica lakes (17), Abesinija Lake (16), the Sava at Rugvica (11) and the Sava at Hrušcica (9), all within $5 \mathrm{~km}$ of the colony on Siromaja 2, were used by all 12 birds breeding there. They spent a vast majority of their time ( $94.1 \%$ of all locations) in these areas closest to their colony. All five remaining parts of the Sava River between Savica and Prevlaka, within $15 \mathrm{~km}$ of the colony, were used by half or more of the tagged birds, although far less regularly $3.7 \%$ of all locations). The Sava at Hrušćica (9), the Sava at Siromaja (10), the Sava at Rugvica (11) and Abesinija Lake (16) were the only areas commonly used by birds breeding on Siromaja 2.

A much larger number of areas, 12 of them, were used by all four birds breeding at Rakitje. A further 7 were used by two or more birds, completing the entire stretch of the river from the Slovenian border to Prevlaka. Apart from the most popular areas the Sava at Hrušćica (9), Rakitje Lake (20), the Sava near Savica (6) and the Sava at Blato (4), one bird was present commonly on the Sava at Rakitje (3), and another at Abesinija Lake (16). 


\begin{tabular}{|c|c|c|c|c|c|c|c|c|c|}
\hline \multicolumn{7}{|c|}{ Code number of individual tern } & \multirow[b]{2}{*}{$\mathrm{N}$} & \multicolumn{2}{|r|}{ statistics } \\
\hline 961032 & 961033 & 961034 & 961035 & 961036 & all terns & $\%$ locations & & $>=10 \%$ & Cummulative \% \\
\hline 1377 & 2050 & 1529 & 932 & 1316 & 18132 & 100.0 & & & \\
\hline 82 & 107 & 178 & 181 & 37 & 1308 & 17.6 & 12 & 10 & 17.6 \\
\hline 14 & 11 & 9 & 3 & 1 & 84 & 1.1 & 12 & 0 & 18.7 \\
\hline 499 & 53 & 116 & 7 & 7 & 1539 & 20.7 & 12 & 6 & 39.5 \\
\hline 178 & 128 & 28 & 66 & 48 & 666 & 9.0 & 12 & 7 & 48.4 \\
\hline 161 & 442 & 419 & 287 & 142 & 3390 & 45.6 & 12 & 11 & 94.1 \\
\hline 8 & 11 & 6 & 2 & 4 & 42 & 0.6 & 9 & 0 & 94.6 \\
\hline 1 & 12 & 4 & 0 & 11 & 40 & 0.5 & 9 & 0 & 95.2 \\
\hline 0 & 0 & 13 & 11 & 5 & 66 & 0.9 & 4 & 0 & 96.0 \\
\hline 8 & 25 & 2 & 1 & 1 & 38 & 0.5 & 6 & 0 & 96.6 \\
\hline 4 & 32 & 2 & 0 & 20 & 69 & 0.9 & 8 & 0 & 97.5 \\
\hline 3 & 2 & 1 & 0 & 0 & 7 & 0.1 & 4 & 0 & 97.6 \\
\hline 3 & 1 & 1 & 0 & 7 & 23 & 0.3 & 8 & 0 & 97.9 \\
\hline 2 & 0 & 0 & 0 & 3 & 8 & 0.1 & 4 & 0 & 98.0 \\
\hline 3 & 0 & 0 & 0 & 2 & 19 & 0.3 & 4 & 0 & 98.3 \\
\hline 4 & 0 & 0 & 0 & 8 & 14 & 0.2 & 3 & 0 & 98.4 \\
\hline 11 & 0 & 0 & 0 & 29 & 62 & 0.8 & 4 & 0 & 99.3 \\
\hline 3 & 0 & 0 & 0 & 15 & 21 & 0.3 & 3 & 0 & 99.6 \\
\hline 0 & 0 & 0 & 0 & 2 & 2 & 0.0 & 1 & 0 & 99.6 \\
\hline 0 & 31 & 0 & 0 & 0 & 31 & 0.4 & 1 & 0 & 100.0 \\
\hline 984 & 855 & 779 & 558 & 342 & 7429 & & & & \\
\hline
\end{tabular}

\section{Discussion}

A little more that $42 \%$ of locations obtained by tags in Slovenia were from breeding islands, while terns spent more time in Croatian colonies $(70.9 \%$ on Siromaja 2 and $57 \%$ on Rakitje). To some point the number of locations on breeding islands is a consequence of the time when terns were caught and fitted with the tag. Our aim was to do this as late during incubation period as possible, preferably in the last two days of incubation. To minimize disturbance, we did not monitor the colony on a daily basis, so we were not able to determine hatching day/last days of incubation period with great precision. The earlier we caught the terns during incubation period, the more days it spent incubating the eggs, which increased the number of locations from this area. This rationale might seem to clash with data from Croatia: birds from the Rakitje colony were tracked from the first day of nesting because they had been equipped with devices beforehand on Lake Siromaja 2. Birds breeding at Siromaja 2, on the other hand, were tagged in mid-incubation and yet they had more colony points than birds at Rakitje. A possible cause for that might be polygon outlining - the Siromaja 2 colony polygon 
D. Tome et al.: Area use and important areas for Common Tern Sterna hirundo inland populations breeding in Slovenia and Croatia

includes the entire lake since smaller platform size, GPS error and lake size led to "colony" points being scattered across almost half of the lake, while the Rakitje and Ptuj colony polygons included only the breeding islands. It is thus inevitable to surmise that Siromaja 2 points include foraging activity as well, while Rakitje and Ptuj colony points include only breeding activity and resting.

At any rate, breeding islands that were determined by us as separate areas within Lakes

Table 4: Number of locations in particular areas for Common Terns from Rakitje. Abbreviations the same as in Table 2.

Tabela 4: Število lokacij v posameznih območjih za čigre z Rakitja. Okrajšave enake kot v tabeli 2.

\begin{tabular}{|c|c|c|c|c|c|c|c|c|c|c|c|}
\hline & \multirow[t]{2}{*}{ Area } & \multicolumn{7}{|c|}{ Code number of individual tern } & \multicolumn{3}{|r|}{ statistics } \\
\hline & & $\begin{array}{l}\text { dis- } \\
\operatorname{tance} \\
(\mathrm{m})\end{array}$ & 961020 & 961022 & 961025 & 961028 & $\begin{array}{r}\text { all } \\
\text { terns }\end{array}$ & $\begin{array}{l}\% \text { loca- } \\
\text { tions }\end{array}$ & $\mathrm{N}$ & $>=10 \%$ & $\begin{array}{l}\text { Cum- } \\
\text { mula- } \\
\text { tive } \%\end{array}$ \\
\hline & Rakitje colony & & 772 & 999 & 1299 & 1492 & 4562 & 100.0 & & & \\
\hline 20 & Rakitje lake & 500 & 74 & 399 & 23 & 59 & 555 & 16.1 & 4 & 2 & 16.1 \\
\hline 3 & Sava at Rakitje & 700 & 21 & 61 & 95 & 38 & 215 & 6.2 & 4 & 1 & 22.4 \\
\hline 21 & Kerestinec & 2900 & 0 & 6 & 0 & 0 & 6 & 0.2 & 1 & 0 & 22.5 \\
\hline 2 & $\begin{array}{l}\text { Sava at Strmec \& } \\
\text { Orešje }\end{array}$ & 4000 & 3 & 16 & 25 & 2 & 46 & 1.3 & 4 & 0 & 23.9 \\
\hline 4 & Sava at Blato & 4700 & 34 & 127 & 51 & 136 & 348 & 10.1 & 4 & 2 & 34.0 \\
\hline 18 & Jarun lake & 6800 & 3 & 14 & 7 & 17 & 41 & 1.2 & 4 & 0 & 35.2 \\
\hline 5 & Sava Jarun-Bundek & 9100 & 23 & 65 & 26 & 40 & 154 & 4.5 & 4 & 0 & 39.7 \\
\hline 1 & Sava 1 & 9700 & 0 & 3 & 7 & 0 & 10 & 0.3 & 2 & 0 & 39.9 \\
\hline 5 & Bundek & 11300 & 0 & 7 & 1 & 3 & 11 & 0.3 & 3 & 0 & 40.3 \\
\hline 6 & Sava near Savica & 13100 & 28 & 210 & 65 & 104 & 407 & 11.8 & 4 & 3 & 52.1 \\
\hline 29 & Savica reserve & 14700 & 0 & 2 & 0 & 4 & 6 & 0.2 & 2 & 0 & 52.3 \\
\hline 7 & Sava at Petruševec & 17400 & 51 & 99 & 24 & 77 & 251 & 7.3 & 4 & 0 & 59.6 \\
\hline 8 & Sava at Ščitarjevo & 20500 & 12 & 32 & 14 & 13 & 71 & 2.1 & 4 & 0 & 61.6 \\
\hline 22 & Crna Mlaka fishponds & 22700 & 0 & 3 & 3 & 0 & 6 & 0.2 & 2 & 0 & 61.8 \\
\hline 9 & Sava at Hrušćica & 23700 & 186 & 375 & 76 & 215 & 852 & 24.8 & 4 & 4 & 86.5 \\
\hline 10 & Sava at Siromaja & 23700 & 37 & 42 & 18 & 32 & 129 & 3.7 & 4 & 0 & 90.3 \\
\hline \multirow[t]{2}{*}{16} & Abesinija lake & 25200 & 89 & 0 & 0 & 0 & 89 & 2.6 & 1 & 1 & 92.9 \\
\hline & Siromaja colony & 27100 & 25 & 2 & 0 & 54 & 81 & 2.4 & 3 & 0 & 95.2 \\
\hline 11 & Sava at Rugvica & 27500 & 42 & 8 & 9 & 20 & 79 & 2.3 & 4 & 0 & 97.5 \\
\hline 12 & Sava Novaki-Oborovo & 30200 & 3 & 0 & 4 & 8 & 15 & 0.4 & 3 & 0 & 98.0 \\
\hline 24 & Puhovec lakes & 30900 & 36 & 0 & 0 & 0 & 36 & 1.0 & 1 & 0 & 99.0 \\
\hline 13 & Sava Oborovo-Prevlaka & 31100 & 0 & 0 & 9 & 1 & 10 & 0.3 & 2 & 0 & 99.3 \\
\hline \multirow[t]{2}{*}{26} & Sišćani fishponds & 66400 & 24 & 0 & 0 & 0 & 24 & 0.7 & 1 & 0 & 100.0 \\
\hline & all areas w/o colony & & 691 & 1471 & 457 & 823 & 3442 & & & & \\
\hline
\end{tabular}


Ptuj and Rakitje and the entire Siromaja 2 Lake, are, for obvious reasons, regarded as important for Common Terns by default, regardless of the number of recorded locations. We excluded those data for the analysis of other areas, so that a difference in the number of days terns spent incubating eggs did not influence further results.

As expected, area use of terns during breeding season relates closely to large water bodies like rivers, lakes and fishponds.

In Slovenia, some areas were dislocated from Lake Ptuj. Terns reached them only after flying up to $26 \mathrm{~km}$ over cultural landscape, where they crossed villages, highways and small forest patches. Sequences of locations showed that they were following the route in a rather straight line, indicating that they must have had previous experience about the location. The largest and continuous part of used area stretched along the Drava from Lake Ormož to Maribor. This is about $60 \mathrm{~km}$ long and very narrow part which terns seem to exploit simply by following the course of the Drava River. The most remote location from nesting ground was the Drava close to the village of Bresternica, NW of Maribor. It was about $30 \mathrm{~km}$ of straight line from nesting ground and was visited once by one tern only.

The most used areas (beside nesting islands) were the Drava river-bed between Ptuj and Rošnja, the Drava at Ptuj and Lake Ptuj. These are all neighbouring areas, together forming a large important area, which also includes breeding islands. Two areas that were almost $20 \mathrm{~km}$ of straight line away from the Drava, Gradiško Lake and in particular Lake Radehova, turned out to be important as well. The latter was used by 5 terns, four of which were commonly present in the area. As expected, the artificial channel with fast and deep water flow, which runs almost parallel to the Drava river-bed, turned out to be a totally inappropriate habitat for terns.

Compared to birds from Ptuj, terns in Croatia usually stayed much closer to the Sava River, very rarely straying more than $2 \mathrm{~km}$ from the river. The single most important area for birds from both Croatian colonies was part of the Sava River at Hrušćica, which is not surprisingly a Natura 2000 protected area (RADOvić et al. 2005.). Apart from breeding within the boundaries of this Important
Bird Area, $85 \%$ of localities of birds from the Siromaja colony were there as well, aligned along the river or at Lake Abesinija, and another 9\% immediately downstream. Even birds from the Rakitje colony regularly travelled $25 \mathrm{~km}$ to have a third of their locations there. Other areas identified as important for birds breeding on Rakitje were the Sava near Savica and, closer to their own colony, the Sava at Blato and the Sava at Rakitje, as well as Lake Rakitje itself.

There is a catch in our data which should be considered when interpreting the results. While tags gave us relatively exact locations of terns in exact time, there was no way we could read from them what they were doing while on the location. For locations within nesting area we can more or less accurately say that birds were involved in breeding routine, whether incubating the eggs or caring for their chicks. A certain proportion of readings from this area was possibly also recorded during resting time. On the other hand, it is impossible to interpret activities of terns in other locations with such ease. But we believe that the majority of them belong to two types of activity: hunting (catching and searching for prey) and flying.

Several locations outside the nesting site were definitively recorded during hunting activity, but some were almost certainly recorded also during flights, when terns were on their way to reach more distant hunting areas. In practice this means that some locations on Lake Ptuj and on the Drava at Ptuj were possibly obtained during flights to a hunting place on the Drava river-bed between Ptuj and Maribor and not during a hunt. The ratio between flying and hunting activity is impossible to quantify, but we presume that a higher proportion of flying activity was recorded closest to the nesting area than in more distant areas. It is thus possible that importance of some areas near the nesting place is both as a flying corridor toward hunting locations as well as a hunting area itself, while more distant ones probably had greater proportion of hunting activities as opposed to flying.

With this in mind, we believe that the most important hunting areas for Common Terns in Slovenia were the Drava river-bed from Ptuj to Rošnja, Gradiško Lake and Lake Radehova. Lake Ptuj and the Drava at Ptuj were definitely important as flying corridors and, to a certain level, as hunting 
D. Tome et al.: Area use and important areas for Common Tern Sterna hirundo inland populations breeding in Slovenia and Croatia

areas too. The latter is confirmed by regular observations of terns foraging in these areas.

Taking this into account with Croatian colonies, the importance for terns breeding at Rakitje of the far-away Sava at Hrušcica becomes even more obvious, and to a lesser extent that of the Sava near Savica. On the other hand, the Sava at Rakitje and the Sava at Blato both probably serve a dual purpose of feeding area and flight corridor.

Common Terns mostly fish within 3 to $10 \mathrm{~km}$ of the breeding grounds, with longest foraging distances being over $30 \mathrm{~km}$ (BECKER \& LUDWIGS 2004). The longest distances to the most frequently visited areas in this research were in this range, although rather different between locations: from $4 \mathrm{~km}$ at Siromaja, to 20 and $24 \mathrm{~km}$ in Ptuj and Rakitje, respectively. The overall longest distance (it was made by two terns) was stunning $65 \mathrm{~km}$. This distance corresponds roughly to the distance between Slovenian and Croatian breeding colonies at Ptuj and near Zagreb. Nevertheless, we did not find any evidence that terns from these colonies were in any kind of contact. On the other hand, results showed possible interactions between terns from the colony at Ptuj with the ones on Croatian side of Lake Ormož. Also, although not a single location of terns from Croatia was found on Slovenian side of the Sava, recoveries of ringed birds (Archives of Ringing Centers Zagreb and Ljubljana) showed that terns from Rakitje and Blato colonies do disperse to the colony on the Sava near Brežice.

We recommend conducting further studies of how environmental factors such as hydrology and productivity influence area use. These are necessary in order to explain why areas like the Sava at Hrušcica and the Sava near Savica in Croatia, and Gradiško and Radehova Lakes in Slovenia are so favourable that birds are willing to fly $20-25 \mathrm{~km}$ to reach them instead of staying closer to their colony. More detailed analyses of home range are also necessary.

Acknowledgement: Research funding was provided by the Cooperation Programme Interreg V-A Slovenia - Croatia (grant SLO-HR347). Permits for tagging and ringing of the birds were issued by relevant authorities (MOP in Slovenia and MZOE in Croatia).

\section{Povzetek}

V sezonah 2018 in 2019 smo raziskovali območja, ki jih navadne čigre (Sterna hirundo) obiskujejo med gnezdenjem. Z GPS-UHF-oddajniki smo sledili 23 čiger iz Slovenije (7 osebkov) in Hrvaške (16 osebkov). Ptice smo ujeli na treh gnezdiščih: Ptujsko jezero, Siromaja 2 in Rakitje. Zaključki so narejeni na osnovi 43.105 podatkov o lokacijah, ki smo jih zbirali s frekvenco en odčitek na vsakih 20 minut podnevi oz. en odčitek na vsake 4 ure ponoči.

V Sloveniji so čigre letale nad $60 \mathrm{~km}$ dolgim, ozkim območjem Drave od Ormoža do Maribora in nad enajstimi ribniki / jezeri v okolici, večinoma v dolini Pesnice. Najbolj oddaljena lokacija od gnezdišča je bila $30 \mathrm{~km} v$ ravni črti, a tako daleč se je odpravila le ena čigra, in to enkrat samkrat. Najpogosteje so se čigre zadrževale na stari strugi Drave med Ptujem in Rošnjo, na Ptujskem jezeru, na Dravi pri Ptuju ter na jezerih Radehova in Gradiško. Slednji sta oddaljeni okoli $20 \mathrm{~km}$ od gnezdišča. To so bila v celinskem delu Slovenije verjetno najpomembnejša območja, na katerih so čigre v času gnezdenja iskale hrano.

$\mathrm{Na}$ Hrvaškem so čigre večinoma letale nad Savo, le izjemoma so se oddaljile tudi več kot $2 \mathrm{~km}$ stran od struge. Najdaljša razdalja od gnezdišča je bila več kot $60 \mathrm{~km}$, a tam smo zabeležili zelo majhno število obiskov. Ptice iz kolonije Siromaja 2 so se večinoma zadrževale $\mathrm{v}$ radiju do $5 \mathrm{~km}$ od gnezdišča, medtem ko so ptice iz kolonije Rakitje redno letale do $23 \mathrm{~km}$ oddaljenih območij. Najpogosteje obiskano območje za čigre iz Siromaje in Rakitja je bila Sava pri Hrušćici. Ptice iz kolonije v Rakitju so redno obiskovale tudi Savo pri Savici in nekatere vodne površine v radiju $5 \mathrm{~km}$. To so bila v okolici Zagreba verjetno najpomembnejša območja, na katerih so čigre v času gnezdenja iskale hrano.

\section{References}

Becker, P.H., Ludwigs, J-D. (2004): Common Tern: in Birds of the western palearctic, IV, . ed. Cramp, S., Oxford University Press.

Božič, L. (2003): Mednarodno pomembna območja za ptice v Sloveniji 2. Predlogi posebnih zaščitenih območij (SPA) v Sloveniji. DOPPS, Monografija DOPPS Št. 2, Ljubljana.

Božič, L., Denac D. (2014): Reka Drava : darilo narave za vse generacije. DOPPS. 
Dänhard, A., Fresemann, T., Becker, P.H. (2011): To eat or to feed? Prey utilization of Common Terns Sterna hirundo in the Wadden Sea. Journal of Ornithology 152 (2): 345-357.

DenaC, D., Božıč, L. (2018): Upravljanje za varstvo navadne čigre v Sloveniji. Svet ptic 3: 14-19. DOPPS.

DenaC, D., ŠKornik, I., Božıč, L., Mozetič, B. (2019): Navadna čigra Sterna hirundo. pp. 196-197. In: Mihelič T., Kmecl P., Denac K., Koce U., Vrezec A., Denac D. (eds.): Atlas ptic Slovenije. Popis gnezdilk 2002-2017. - DOPPS, Ljubljana.

EEA. (2015): State of nature in the EU - Results from reporting under the nature directives 2007-2012. Technical report 2, European Environment Agency.

Holbech, L.H., Gbogbo, F., Aikins, T. K. (2018): Abundance and prey capture success of Common Tern (Sterna hirundo) and Pied Kingfisher (Ceryle rudis) in relation to water clearity in south-east coastal Ghana. Avian Research 9: 25. https://doi. org/10.1186/s40657-018-0116-7

JANŽEKOVIČ F., ŠTUMBERGER B. (1984): Otoka na Ptujskem jezeru zaščitena. Acrocephalus 5 (22): 54-56.

KRALJ, J. (2018): Raziskovanje čiger na Hrvaškem. Svet ptic 3: 22-24. DOPPS.

KRALJ, J., Barišić, S., Tutiš, V., Ćiković, D. (eds.) (2013): Atlas selidbe ptica Hrvatske. - HAZU.

Martinović M., Galov A., Svetličić I., Tome D., JuRinović L., JeČMENicA B., BASLE T., BožIČ L., Kralj J. (2019): Prospecting of breeding adult Common terns in an unstable environment. Ethology Ecology \& Evolution. https://doi.org/10.1 080/03949370.2019.1625952

Martinović, M. (2018): Varstvo navadne čigre na Hrvaškem. - Svet ptic 3: 25-27. DOPPS.

Minelič T., Kmecl P., Denac K., Koce U., Vrezec A. Denac D. (eds.) (2019): Atlas ptic Slovenije. Popis gnezdilk 2002-2017. - DOPPS, Ljubljana.

Newton, I. (2007): population limitation in birds: the last 100 years. British birds 100: 518-539.

NisBet, I.C.T. (2002): Common Tern: In The Birds of North America, No 618, eds. Poole, A. \& Gill F., Birds of North America, Philadelphia.

PyKe, G.H. (1984): Optimal foraging theory: a critical review. Ann. Rev. Ecol. Syst. 15: 523-575.

QGIS Development Team (2016): QGIS Geographic Information System. Open Source Geospatial Foundation Project. http://qgis.osgeo.org

Radović D., Kralj, J., Tutiš, V., Radović, J., Topić, R. (2005): Nacionalna ekološka mreža - važna područja za ptice u Hrvatskoj. - DZZP.

ŠKORNIK. I. (2012): Favnistični in ekološki pregled ptic Sečoveljskih solin. Soline Pridelava soli doo.

SLukan Altić, M. (2010): Povijest regulacije rijeke Save kod Zagreba i njezine posljedice na izgradnju grada. Hrvatske vode 18(2010) 73 205-212.
Vogrin, M. (2016): Monitoring ptic na Ptujskem jezeru. Strokovno poročilo. http://www.ptuj.si/_pdf/monitoring-ptic-2016.pdf

WeTteR, J.K. (1989): Central place foraging theory: when load size affect travel time. Theoretical population biology 36(3): 267-280.

Prispelo / Arrived: 3.10.2019

Sprejeto / Accepted: 25.11.2019 